Miss A. V. H. (27 years)

$1200 \mathrm{kcal}$ diet

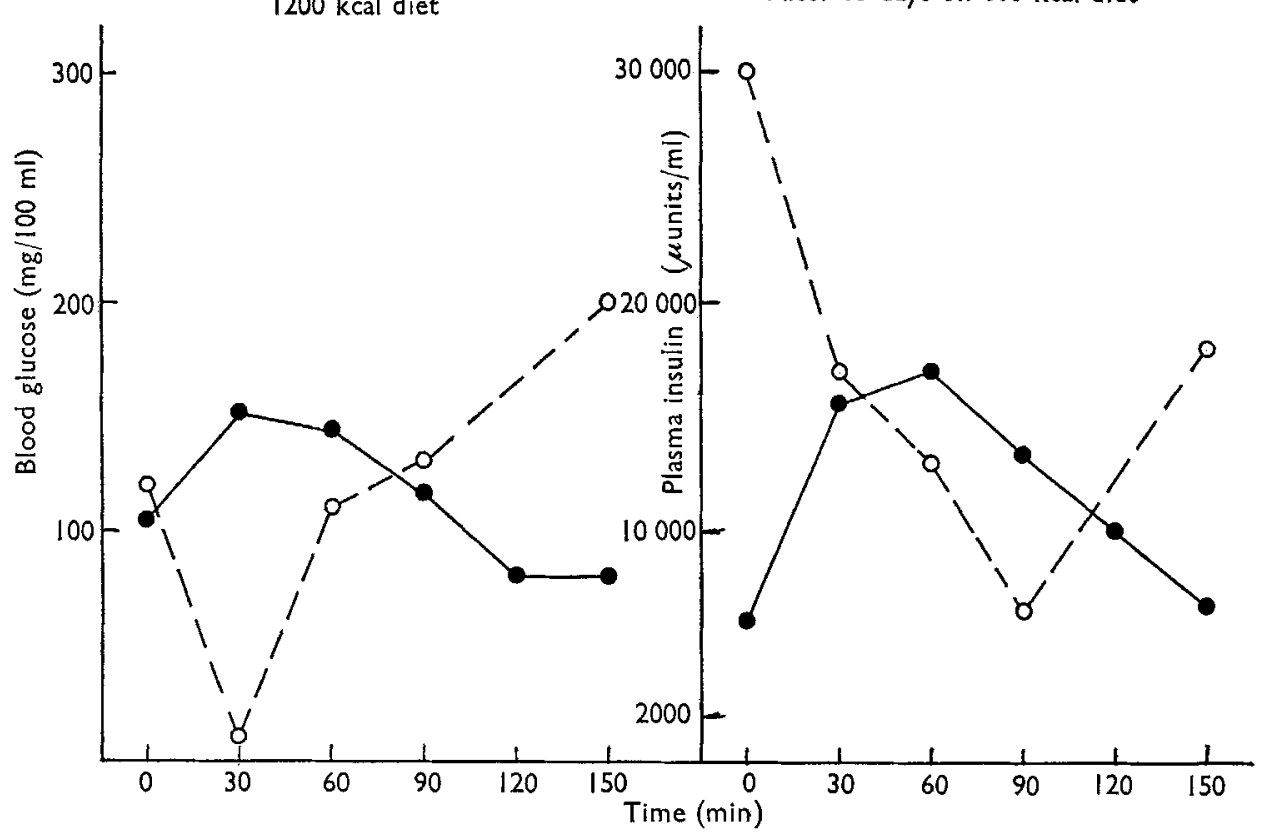

Fig. 8. Oral glucose tolerance and plasma insulin levels in obese woman before and after 39-day period on $600 \mathrm{kcal}$ diet. Note extreme hyperinsulinism with normal glucose tolerance. $0-0$, plasma insulin.

changes in plasma insulin level were concerned with these changes in glucose tolerance.

Acknowledgement is gratefully made for support given to this work by the Medical Research Council.

\title{
REFERENCES
}

Bierman, E. L., Dole, V. P. \& Roberts, J. N. (I957). Diabetes, 6, 47.

Duncan, L. J. P. (1956). Q. Fl exp. Physiol. 4r, 85 .

Duncombe, W. G. (1963). Biochem. Y. 88, 77.

Hales, C. N. (1966). Proc. Nutr. Soc. 25, 61.

Hales, C. N. \& Randle, P. J. (1963a). Biochem. F. 88, I37.

Hales, C. N. \& Randle, P. J. (1963b). Lancet, i, 790 .

Randle, P. J., Garland, P. B., Hales, C. N. \& Newsholme, E. A. (1963). Lancet, i, 785.

Reid, R. L. (1960). Analyst, 85, 265.

Schalch, D. S. \& Kipnis, D. M. (1964). Abstract, 56th Annual Meeting of the American Society for Clinical Investigation.

Van Handel, E. \& Zilversmit, D. B. (1957). Ұ. Lab. clin. Med. 50, 152.

Werk, E. E. Jr. \& Knowles, H. C. Jr. (1961). Diabetes, ro, 22.

\section{Control of dietary fat in relation to diabetic complications in children}

\section{By June K. Lloyd, Institute of Child Health, University of London}

The aetiology and prevention of vascular complications is now one of the outstanding problems in the management of childhood diabetes mellitus. Most of the work related to the prevention of the vascular lesions in the juvenile diabetic has 
been concerned with the control of carbohydrate metabolism, but the importance of the role of diabetic control in this respect remains controversial.

That disordered fat metabolism might contribute to the arteriosclerotic lesions in diabetes was suggested by Joslin (1928), and he also speculated that the dietary intake of fat might be of importance in this respect. The association of hyperlipidaemia and atherosclerosis in the non-diabetic individual is now well established (Kannel, Dawber, Friedman, Glennon \& McNamarra, 1964). There is no evidence that atherosclerotic lesions are different in diabetics and non-diabetics (Alterman, I960) and the serum lipid abnormalities found in uncomplicated diabetes resemble those found in the non-diabetic with atherosclerosis (Demanet, Gregoire \& Bastenie, 1959). Modifications in the dietary fat intake, whether by reduction in total quantity or the use of polyunsaturated fats, have been shown to affect the serum lipid pattern in both non-diabetic and diabetic individuals (Ahrens, Hirsch, Insull, Tsaltas, Blomstrand \& Peterson, 1957; Kinsell, Michaels, Walker, Wheeler, Splitter \& Flynn, 1959; Dayton, Pearce, Hashimoto, Fakler, Hiscock \& Dixon, r 962 ; Stone \& Connor, 1963 ), and a relative absence of vascular complications has been reported in cases of diabetes in communities where the fat intake is traditionally low (Rudnick \& Anderson, I962; Brunner, Loebl, Altman, Neiken \& Reider, I964). Reduction of the serum lipids by dietary measures has also been shown to improve established retinopathy in adult diabetic patients (Van Eck, I959; King, Dobree, Kok, Foulds \& Dangerfield, 1963 ). The lowering of serum lipids, whether by oestrogens (Oliver \& Boyd, r 96 I) or an unsaturated-fat diet (Rose, Thompson \& Williams, I965), has not, however, been shown to improve the prognosis of established coronary disease in non-diabetic adults.

The effect of measures designed to lower the serum lipids, which have been instituted before the onset of atherosclerotic lesions, on the subsequent development of such lesions has not been studied. Childhood is obviously the ideal time to commence measures intended to be preventive and Reisman (1965), whilst advocating a reappraisal of the fat content of the diet of all children, considers especially the problem of the diabetic child in the following words: 'Perhaps, above all, children with diabetes who suffer from a disease well known to be associated with an early increase in certain blood lipid fractions and with premature clinical atherosclerosis should be considered candidates for a "hypolipemogenic" diet.'

The study now described concerns the early years of a long-term prospective trial of a diet rich in unsaturated fat given to diabetic children from the time of diagnosis. The initial object of the trial was to see whether such a diet, which has been shown to lower certain lipid fractions in diabetic children on a short-term basis under hospital conditions (Salt, Wolff, Nestadt \& Lloyd, I960), is practicable in the long-term management of juvenile diabetics in their own homes, and whether it will maintain lower levels of lipid in the serum. The ultimate object of the trial is to see whether the incidence and severity of vascular complications differ in children whose serum lipids have been lowered by the dietary measures, compared with children with diabetes of similar duration, whose management has been the same as that of the experimental group apart from the alterations in dietary fat.

25 (1) 6 


\section{Material and methods}

The experimental group consisted of twenty-two newly diagnosed diabetic children of ages ranging from 2 to 12 years who were given a diet in which most of the fat was unsaturated and in the form of corn (maize) oil; this group will subsequently be referred to as the corn oil group. The diet was first given to all children within 2-3 weeks of diagnosis. Another group of nineteen diabetic children with similar disease duration and age range has been used as a control: their dietary fat was unaltered and therefore largely saturated. The children were assigned, as far as possible, alternately to the corn oil and control groups. The purpose of the trial was explained to the parents of the children designated for the corn oil group and their co-operation invited. The parents of the control children were not told that their children were participating in a dietary trial. Over the years four of the children have been withdrawn from the corn oil group.

The details of the corn oil diet were as described by Lloyd \& Jukes (I96I). In both groups only the carbohydrate content of the diet was controlled, no exact measurements being made of either fat or protein. Assessments of the dietary composition made from records kept at home are shown in Table $\mathrm{r}$. The percentage of total daily calories derived from the three major classes of foodstuffs was similar in both groups, about $45 \%$ of calories being derived from carbohydrate, $42 \%$ from fat and $13 \%$ from protein. In the corn oil group, on average, $80 \%$ of the total fat intake was in the form of corn oil, the remaining $20 \%$ being mainly of animal origin.

Routine diabetic management, as practised at the Birmingham Children's Hospital, was as follows and was common to both groups. All the children had insulin, usually a long-acting preparation given once daily. Only the carbohydrate content of the diet was regulated in amount. The urine was tested at least twice daily for sugar and ketones and the parents were encouraged to make such adjustments in insulin dose and dietary carbohydrate as necessary. All children were seen regularly in the diabetic clinic where the urine was tested for sugar, ketones and protein. Diabetic control was assessed clincially as either 'good', 'fair' or 'poor'. Blood sugar was not estimated as a routine but in the two trial groups blood was taken for lipid analyses every 6 months and on this occasion a blood sugar estimation was also made.

Serum total lipid was estimated by the method of de la Huerga, Yesinick \& Popper (1953), total cholesterol by the method of Sackett (1925), lipoprotein lipid by the

Table I. Percentage of total daily calories derived by diabetic children from carbohydrate, protein and fat

(Mean values and ranges)

$\begin{array}{lccccc}\text { Dietary group } & \text { Carbohydrate } & \text { Protein } & \overbrace{\text { Total }} & \text { 'Animal' } & \text { Corn oil } \\ \text { Corn oil } & \begin{array}{c}47 \\ (42-52)\end{array} & \begin{array}{c}12 \\ (11-15)\end{array} & \begin{array}{c}40 \\ (36-44)\end{array} & \begin{array}{c}8 \\ (5-15)\end{array} & \begin{array}{c}32 \\ (27-37)\end{array} \\ \text { Control } & \begin{array}{c}44 \\ (40-48)\end{array} & \begin{array}{c}13 \\ (11-16)\end{array} & \begin{array}{c}43 \\ (39-48)\end{array} & & \end{array}$


method of Salt \& Wolff (I957), and blood sugar by the Folin-Wu micro-technique (Harrison, 1937).

Assessments of the vascular status of the children were made by clinical examination including ophthalmoscopic examination of the retinas, estimation of urine protein excretion, microscopic examination of the small vessels of the bulbar conjunctivae, and the responses of the small blood vessels of the feet to reflex vasodilation. Details of these investigations will form the subject of a separate communication.

\section{Results}

Serum lipids. At the time of admission, before the first dose of insulin had been given, the mean values for the serum lipids and blood sugar were not significantly different between the two groups (Table 2). In both groups insulin treatment resulted in a fall of the elevated lipids to values within the normal range. The results of estimations of the serum lipids made at follow-up examinations after 6 to 68 months duration of diabetes are shown in Fig. I. The mean values of total lipid, total cholesterol, $\beta$-lipoprotein lipid and the ratio of $\beta$ - to $\alpha$-lipoprotein lipids remained consistently lower for the corn oil group compared with the control group of

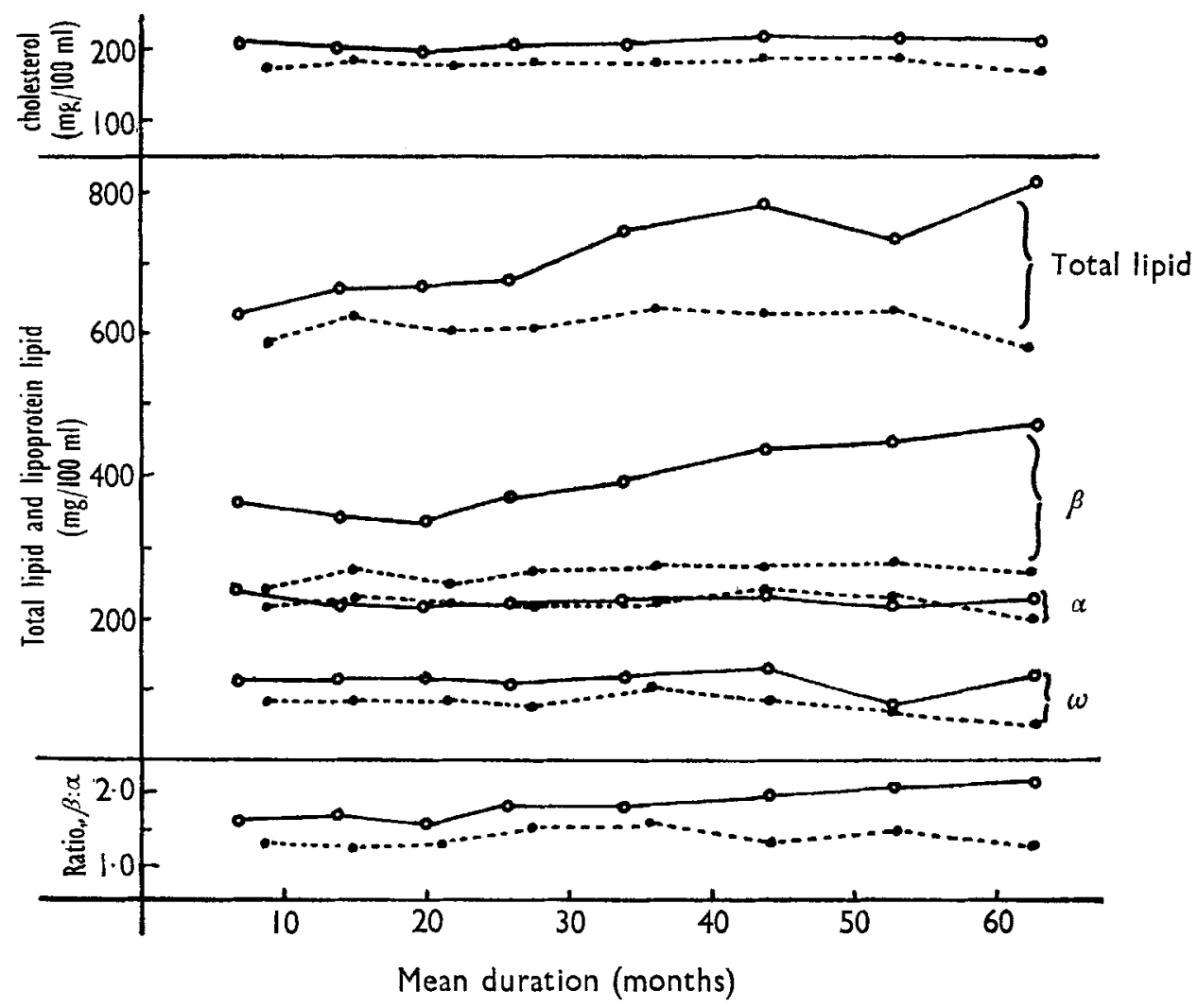

Fig. I. Mean serum lipid and lipoprotein levels in children with increasing duration of diabetes. $\mathrm{O}-\mathrm{O}$, control group; - - $\mathbf{0}$, corn oil group. 
Table 2. Serum lipids and blood sugar concentrations $(\mathrm{mg} / \mathrm{roo} \mathrm{ml})$ in diabetic children at the time of diagnosis

(Mean values and standard deviations)

\begin{tabular}{|c|c|c|c|c|c|c|c|c|}
\hline \multirow{3}{*}{$\begin{array}{l}\text { Dietary group } \\
\text { Corn oil* }\end{array}$} & \multirow{3}{*}{$\begin{array}{l}\text { No. of } \\
\text { children } \\
20\end{array}$} & \multirow{3}{*}{$\begin{array}{c}\text { Blood } \\
\text { sugar } \\
474 \pm 29 \mathrm{I}\end{array}$} & \multirow{3}{*}{$\begin{array}{c}\text { Total } \\
\text { lipid } \\
\text { I078 } 8409\end{array}$} & \multirow{3}{*}{$\begin{array}{c}\text { Total } \\
\text { cholesterol } \\
224 \pm 76\end{array}$} & \multicolumn{3}{|c|}{ Lipoprotein lipid } & \multirow{3}{*}{$\begin{array}{c}\text { Ratio, } \\
\beta: \alpha \\
3 \cdot 9 \pm 3 \cdot 7\end{array}$} \\
\hline & & & & & $\omega$ & $\beta$ & $\alpha$ & \\
\hline & & & & & $170 \pm 138$ & $706 \pm 523$ & 2.02 上43 & \\
\hline Control & I9 & $436 \pm 232$ & $1032 \pm 400$ & $246 \pm 71$ & $193 \pm 150$ & $645 \pm 343$ & $176 \pm 79$ & $5 \cdot I \pm 5$ \\
\hline
\end{tabular}

*In two of the twenty-two children it was not possible to measure serum lipids before the first injection of insulin.

children. The fact that the consistent difference has been maintained is highly significant. With increasing disease duration the values for total lipid and $\beta$-lipoprotein lipid in the control group showed a slight but significant increase; no such increase occurred in the corn oil group.

Fig. 2 shows the relationship between the mean levels of $\beta$-lipoprotein and the blood sugar at the same time. Whereas in the control group a rise in blood sugar over $200 \mathrm{mg} / 100 \mathrm{ml}$ was associated with an increase in $\beta$-lipoprotein, in the corn oil group there was no increase in $\beta$-lipoprotein with increasing blood sugar.

Diabetic control. Table 3 shows the results of clinical assessments of long-term diabetic control in the two groups. There was no difference in the degree of overall diabetic control between the two groups.

Insulin requirements. The insulin requirements of the children have been expressed as units of insulin $/ \mathrm{kg}$ body-weight per day. Fig. 3 shows the mean require-

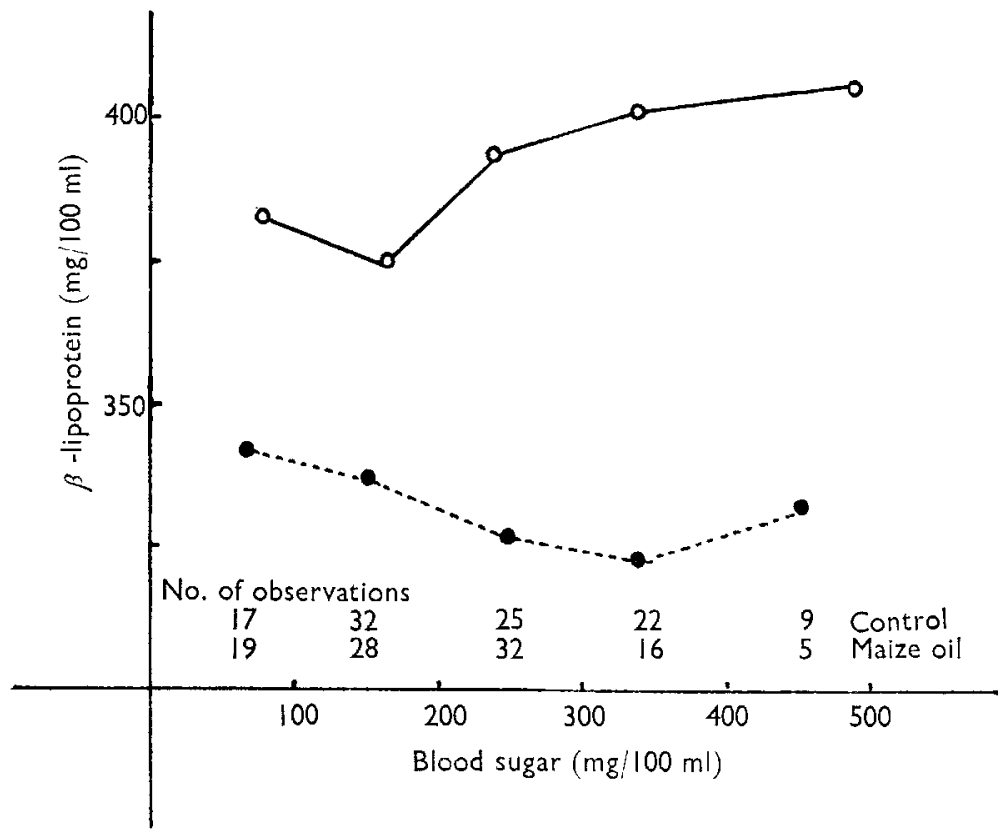

Fig. 2. Relationship between mean $\beta$-lipoprotein and blood sugar contents in diabetic children. $\bigcirc-O$, control group; - - , corn (maize) oil group. 
Table 3. Clinical assessment of long-term diabetic control in children

\begin{tabular}{ccccc} 
Dietary group & No. of & \multicolumn{3}{c}{ Diabetic control } \\
children & Good & Fair & Poor \\
Corn oil & I8 & 5 & 10 & 3 \\
Control & I9 & 8 & 8 & 3
\end{tabular}

ments in the two groups according to age. In the control group mean requirements were of the order of $\mathrm{I} \cdot \mathrm{O}$ unit $/ \mathrm{kg}$ day until the age of I I years when there was a slight increase in requirements. In the corn oil group mean values were significantly lower $(0.8 \mathrm{unit} / \mathrm{kg}$ day) at all ages and there was no tendency for an increase in requirements at puberty. Fig. 4 shows the insulin requirements at follow-up examinations. The values obtained after initial stabilization with insulin (not shown on the figure) did not differ between the two groups but subsequently there was a significant difference between the two groups at all durations after 6-8 months.

Vascular complications. Table 4 summarizes the results of examinations made when the disease duration in the majority of children was about 5 years and in no case exceeded 6 years; details of this study are to be reported separately. Retinopathy was not detected in any child in either group; peripheral neuropathy was found on clinical examination in four children, three of whom were in the control group; proteinuria of an intermittent nature was detected in nearly half the children in the control group and in one-third of the children in the corn oil group; abnormalities of the small vessels of the bulbar conjunctiva were found in $65 \%$ of the children in the control group and in $44 \%$ of the children in the corn oil group and tended

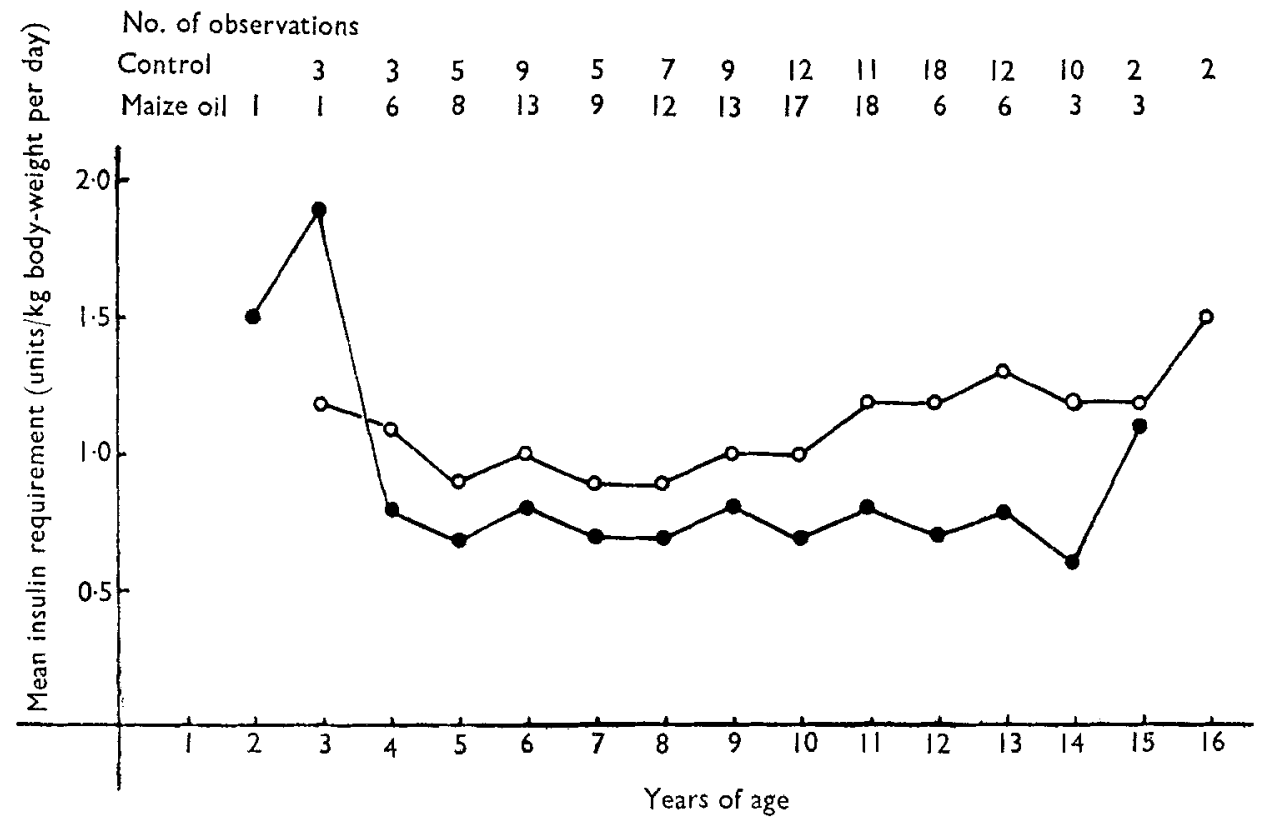

Fig. 3. Insulin requirements of diabetic children according to age. $\mathrm{O}-\mathrm{O}$, control group; corn (maize) oil group. 
No. of observations

$\begin{array}{lllllllll}\text { Control } & 16 & 19 & 13 & 17 & 14 & 13 & 9 & 7 \\ \text { Maize oil } & 21 & 17 & 16 & 15 & 13 & 13 & 9 & 2\end{array}$

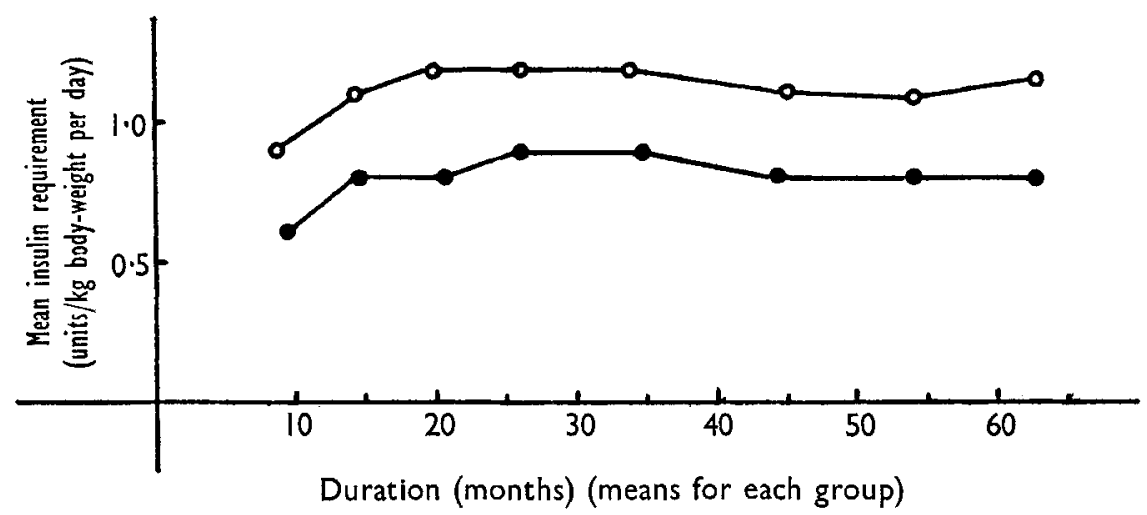

Fig. 4. Insulin requirements of diabetic children according to duration of disease. $\bigcirc-\bigcirc$, control group;

to be more marked in the control group; abnormal responses to reflex vasodilatation in the feet were found with equal frequency in a few children in both groups. All the children tested in the control group had some abnormality and many, of course, had more than one abnormal finding. Of the sixteen children fully assessed in the corn oil group, however, there were five in whom no abnormalities were detected.

\section{Discussion}

The immediate aim of the dietary trial has been accomplished: an unsaturatedfat diet is practicable for diabetic children on a long-term basis at home and maintains lower levels of serum total lipid, cholesterol and $\beta$-lipoprotein than a diet containing largely saturated fat. It is unlikely that the differences in serum lipids

Table 4. Incidence of 'vascular complications' in the dietary groups of children after 5 years' duration of diabetes

\begin{tabular}{|c|c|c|}
\hline \multirow[b]{2}{*}{ 'Vascular complication' } & \multicolumn{2}{|c|}{ No. of children showing complication* } \\
\hline & $\begin{array}{c}\text { Control group } \\
(\text { (17) }\end{array}$ & $\begin{array}{l}\text { Corn oil group } \\
\text { (16) }\end{array}$ \\
\hline opathy & ० & $\circ$ \\
\hline pathy & 4 & I \\
\hline $\begin{array}{l}\text { hittent proteinuria } \\
\text { hormal conjunctival blood }\end{array}$ & 8 & 6 \\
\hline $\begin{array}{l}\text { vessels } \\
\text { ormal response to reflex }\end{array}$ & 12 & 7 \\
\hline vasodilatation in feet & 2 & 3 \\
\hline the above findings & 17 & I I \\
\hline of the above findings & 0 & 5 \\
\hline
\end{tabular}

*Figures in parentheses are the numbers of children fully assessed. 
between the two groups are due either to a reduction in the total quantity of fat in the corn oil group or to better diabetic control in this group. In fact the results of the correlations between $\beta$-lipoprotein and blood sugar suggest that the corn oil diet may prevent the rise in serum lipid that occurs with rising blood sugar and relatively poor control.

The differences in insulin requirements between the two groups were an unexpected finding. By calculating the requirements on a basis of body-weight, differences in the total daily dose due to the slightly different age structure of the groups were eliminated. The mean values for insulin requirement in the control group agree with those reported by Danowski (1957) who has used the same method of calculation, and the lower requirements of the children in the corn oil group were apparent in each age group and at all durations. Cochran, Poucher, Gilliland \& Marbach (1964) have also reported a reduction in insulin requirements in patients having a polyunsaturated-fat diet. Ten of their thirteen patients on insulin were able to decrease their daily dose by 30-100\% with three stopping altogether.

It is only possible to speculate about the reasons for the reduced insulin requirement. Bornstein (1953) reported the presence of an inhibitor to glucose uptake associated with $\beta$-lipoprotein in the serum of diabetic rats. Conceivably therefore a reduction in the amount of $\beta$-lipoprotein might result in a reduction in insulin requirement. If this were the sole explanation for the findings in the study now presented, a direct correlation might be expected between the serum $\beta$-lipoprotein level and the insulin requirement in individual cases. This has not been found and it is unlikely that the lowering of $\beta$-lipoprotein produced by the unsaturated-fat diet is the only reason for the reduced insulin requirement. Randle, Garland, Hales \& Newsholme (1963) have proposed the existence of a glucosefatty acid cycle and suggest that plasma non-esterified fatty acids (NEFA) are inhibitory to insulin action. Although quantitative differences in plasma NEFA have not been shown to occur between children having an unsaturated-fat diet and those having more saturated fat (Fosbrooke \& Lloyd, unpublished findings), the qualitative differences which are present may affect reactions occurring at, or within, the cell membrane.

The influence of the corn oil diet on the vascular complications cannot be evaluated in the short period at present studied. The vascular abnormalities so far detected are confined to the small vessels as distinct from the larger vessels. The finding of abnormalities in a very high proportion of diabetic children at such an early stage of the disease may support the concept that such complications may in some cases even antedate the disorder of carbohydrate metabolism (Colwell, 1965). The failure to detect abnormalities in five out of the sixteen children in the corn oil group does not imply that abnormalities are absent in this group, only that they have not been shown by the methods used. The ultimate effect of an unsaturated-fat diet in preventing or delaying the onset or severity of the vascular complications in the juvenile diabetic can only be determined by the continuation of the dietary trial for a prolonged period. Until such time there is no justification for the routine use of an unsaturated-fat diet for all diabetic children. 


\section{Summary}

A prospective long-term trial of an unsaturated-fat diet for diabetic children has shown that lower levels of serum total lipid, cholesterol and $\beta$-lipoprotein lipid have been maintained, over a 6 -year period, in a group of children whose dietary fat was largely unsaturated (corn oil) compared with the levels in a control group whose dietary fat was largely saturated. In the control group an increase in $\beta$-lipoprotein was observed to occur with both increases in the blood sugar levels and increasing duration of the disease; neither of these findings occurred in the corn oil group. Mean insulin requirements were significantly lower in the corn oil group than in the control group.

No conclusions can yet be drawn regarding the possible effect of the reduction in serum lipids upon the development of the vascular complications of diabetes mellitus.

All the children were investigated at the Birmingham Children's Hospital and I am grateful to the Consultant Staff for permission to study their patients. It is an especial pleasure to thank Professor O. H. Wolff for his encouragement and advice, Miss Audrey S. Fosbrooke for the majority of the biochemical investigations, and Miss Hilda Jukes for invaluable help with the dietary details. The work has been supported by grants from The Medical Research Council and The British Diabetic Association.

\section{REFERENCES}

Ahrens, E. H. Jr., Hirsch, J., Insull, W. Jr., Tsaltas, T. T., Blomstrand, R. \& Peterson, M. L. (1957). Lancet, i, 943 .

Alterman, S. L. (1960). Postgrad. Med. 28, 112.

Bornstein, J. (1953). F. biol. Chem. 205, 513.

Brunner, D., Loebl, K., Altman, S., Neiken, L. \& Reider, J. (1964). Diabetes, 13, 273.

Cochran, B. Jr., Poucher, R. L., Gilliland, J. A. B. \& Marbach, E. P. (1964). Proc. Congr. int. Diabetes Fed. v. Toronto, p. 9.

Colwell, A. R. (I965). Diabetes, r4, I ro.

Danowski, T. S. (1957). Diabetes Mellitus with Emphasis on Children and Young Adults. Baltimore: Williams and Wilkins.

Dayton, S., Pearce, M. L., Hashimoto, S., Fakler, L. J., Hiscock, E. \& Dixon, W. J. (1962). New Engl. F. Med. 266, IoI7.

de la Huerga, J., Yesinick, C. \& Popper, H. (1953). Am. Y. clin. Path. 23, 163.

Demanet, J. C., Gregoire, P. E. \& Bastenie, P. A. (1959). Circulation, 19, 863.

Harrison, G. A. (1937). Chemical Methods in Clinical Medicine, 2nd ed., p.147. London: Churchill and Co. Ltd.

Joslin, E. P. (1928). The Treatment of Diabetes Mellitus, 4th ed. Philadelphia: Lea and Febiger.

Kannel, W. B., Dawber, T. R., Friedman, G. D., Glennon, W. E. \& McNamarra, P. (I964). Ann. intern. Med. 6r, 888 .

King, R. C., Dobree, J. H., Kok, D’A., Foulds, W. S. \& Dangerfield, W. G. (1963). Br. F. Ophthal. 47,666 .

Kinsell, L. W., Michaels, G. P., Walker, G., Wheeler, P., Splitter, S. \& Flynn, P. (1959). Diabetes, $8,179$.

Lloyd, J. K. \& Jukes, H. R. (196r). Lancet, i, 312.

Oliver, M. F. \& Boyd, G. S. (I96I). Lancet, ii, 499.

Randle, P. J., Garland, P. B., Hales, C. N. \& Newsholme, E. A. (I963). Lancet, i, 785 .

Reisman, M. (1965). F. Pediat, 66, r.

Rose, G. A., Thompson, W. B. \& Williams, R. T. (1965). Br. med.F. i, I 53 I.

Rudnick, P. A. \& Anderson, P. S. (1962). Diabetes, rx, 533. 
Sackett, G. E. (1925). F. biol. Chem. 64, 203.

Salt, H. B. \& Wolff, O. H. (1957). Archs Dis. Childh. 32, 404.

Salt, H. B., Wolff, O. H., Nestadt, A. \& Lloyd, J. K. (I960). Lancet, i, 7ı.

Stone, D. B. \& Connor, N. E. (1963). Diabetes, 12, 127.

Van Eck, W. F. (1959). Am. F. Med. 27, 196.

\section{A dietetic service for diabetics}

\section{By Elizabeth M. Wilson, Royal Infirmary, Edinburgh, 3}

Some form of dietary regimen is required for all diabetics whatever the severity of their disorder and irrespective of whether or not insulin or an oral hypoglycaemic drug is being taken. The best results are usually obtained when the diet is simple and readily understood.

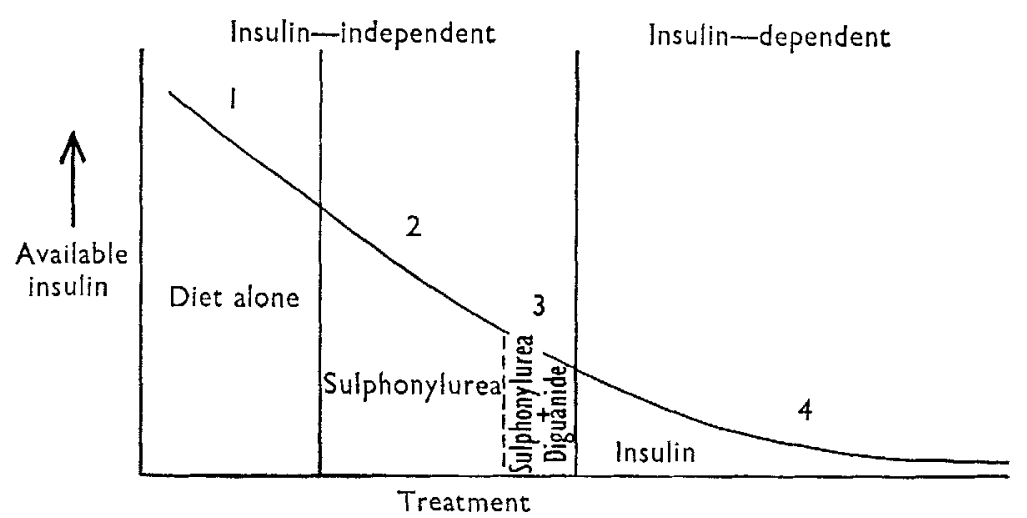

Fig. I. The treatment of diabetes in relation to the patient's ability to produce endogenous insulin.

\section{Classification of diabetes}

Fig. I shows a scheme for the treatment of diabetes in relation to the patient's ability to produce endogenous insulin. If the amount of available insulin is large, treatment is by diet alone; if moderate, it is by diet plus an oral hypoglycaemic agent, and if little or no insulin is being secreted, by diet plus insulin. Diabetics in groups I, 2 and 3 are therefore insulin-independent and those in group 4 insulin-dependent. The diagram can also be interpreted by taking the line of demarcation between 3 and 4 as the age 40 . As a general rule, patients diagnosed to have diabetes before the age of 40 are insulin-dependent and those older than this at diagnosis are insulinindependent.

\section{Principles of diets for diabetics}

Diets for diabetics should conform to the following principles: ( $\mathrm{I}$ ) The avoidance of all forms of concentrated carbohydrate. Simple sugars are quickly absorbed into the bloodstream and cause a rapid postprandial increase in glycaemia, which is difficult to control and may lead to overdosing with insulin. (2) The restriction of, or the prescription in definite quantities of, other forms of carbohydrate. Polysaccharides are more slowly absorbed than sugars, giving a gradual increase 